\title{
GROUND SCINTILLOMETRIC INVESTIGATIONS OF PARTS OF KERRI-KERRI FORMATION, SOUTH - WEST GOMBE, NORTH - EASTERN NIGERIA
}

\author{
D. BACHAMA YUSUF, A. LAWAL AHMED, M. LAWAL KOLA AND A. SULEIMAN ARABI
}

(Received 22 May 2014; Revision Accepted 28 May 2014)

\begin{abstract}
A ground scintillometric survey was carried out in the south - western part of the Kerri - Kerri Formation to identify areas of more prominent radioactive anomalies for further detailed spectrometric investigation. The total count rates recorded were generally higher in the south - western part of the study area. Analysis of the reduced data reveals the threshold activity value for the study area is $27.5 \mathrm{cps}$. Activities of more than twice the mode that will be of significance in terms of mineralization is $40 \mathrm{cps}$ observed in the area north east of Tumu village with occurrence of granitic feldspar. The cosmic ray contribution to the ground activity measured in the field and used for the background correction is $4 \mathrm{cps}$. Detailed ground spectrometric investigation should be carried out in the area north - east of Tumu village to determine the radiometric mineralization potentials of the area and confirm if the radiation is due to the rocks or soil of the area.
\end{abstract}

KEYWORDS: Scintillometric, Total count rates, Background correction, Threshold activity, Mineralization.

\section{INTRODUCTION}

Following the discovery of uranium in Niger Republic and Cameroun, efforts began for the search of the possibility of finding the mineral in Nigeria. Results of such findings gave good indications of the occurrence of uranium ore in Nigeria. Airborne radiometric surveys carried out by the International Resources Inc. USA, in some parts of the country gave the first indications in Nigeria.

Nigeria is blessed with abundant solid mineral resources distributed in all the states of the federation. According to reports by the Nigerian Geological Survey Agency (NGSA), Nigeria has about 34 known major mineral deposits distributed in different locations across the country and offers considerable attractions for investors. These viable solid minerals could be explored and exploited to boost the country's economy and supplement the revenue derived from other resources.

In a quest to explore and exploit the solid minerals, agencies such as the Ministry of Mines and Steel Development, Nigeria Atomic Energy Commission (NAEC), Center for Energy Research and Training (CERT) and the Nigerian Geological Survey Agency (NGSA) were set up to unlock the economic potentials of the solid minerals sub-sector in Nigeria. Geological surveys and airborne geophysical surveys were therefore carried out by these agencies.

In 2007, a regional airborne radiometric survey was conducted by Fugro Airborne Surveys. Some parts of the Kerri - Kerri Formation and Gombe Sandstone are located in the western part of the area of Gombe Sheet 152 S.W. The Ternary Image Map (Fig. 1) of Gombe Sheet 152 S.W. derived from the regional airborne radiometric survey data by the NGSA reveals some radiometric anomalies of uranium, potassium and thorium in the Kerri-Kerri Formation. Also, according to Oshin (1986), the geological setting of the Kerri-Kerri and Bima Formations are potential host of uranium mineralization.

Some geophysical and geological work has been carried out within and around the proposed area of study.

Carter et.al (1963) carried out a study of the geology of parts of Adamawa, Bauchi and Borno Provinces in North-Eastern Nigeria which includes the study area. Arabi, et.al (2009) conducted a Hydro Geo-Electrical Investigation in Gombe town and environs, north eastern Nigeria to determine locations suitable for borehole construction.

A study of the reservoir characterization and evaluation of depositional trend of the Gombe sandstone, southern Chad basin Nigeria was carried out by Adepelumi, et.al (2011). The interpretation of their results suggests that Gombe sandstone in the Chad basin is a potential reservoir for hydrocarbon accumulation. Osazuwa, et.al (1981) carried out an analysis of the Structure of Part of the Upper Benue Rift Valley on the basis of new geophysical data.

Doura M. (2011) conducted a hydro-geophysical

D. Bachama Yusuf, Physics Unit, S.B.R.S., Gombe State University, Gombe State, Nigeria.

A. Lawal Ahmed, Department of Physics, Ahmadu Bello University, Zaria, Nigeria.

M. Lawal Kola, Department of Physics, Ahmadu Bello University, Zaria, Nigeria.

A. Suleiman Arabi, Center for Energy Research and Training, Ahmadu Bello University, Zaria, Nigeria. 
investigation of groundwater potentials in Gombe metropolis sheet 152, north eastern Nigeria and suggested that the major lithologic units penetrated by sounding were lateritic, clay, shale, sandstone and sandy clay while the depth to aquiferous layers ranges between $20-30 \mathrm{~m}$.

There has been no radiometric ground follow up survey to confirm the potentials of uranium mineralization in the Kerri-Kerri Formation, hence the present work can therefore be considered as the first ground radiometric investigation to delineate favorable uranium targets in some parts of the Kerri-Kerri Formation.

\section{AIM AND OBJECTIVES}

The main aim of carrying out this investigation is to identify areas of more prominent radioactive anomalies within the study area. This aim will be achieved by:

$>$ Taking total count readings randomly in the study area with a scintillometer

$>$ Analysis of the reduced data and

$>$ Comparing the results with the geology of the area.

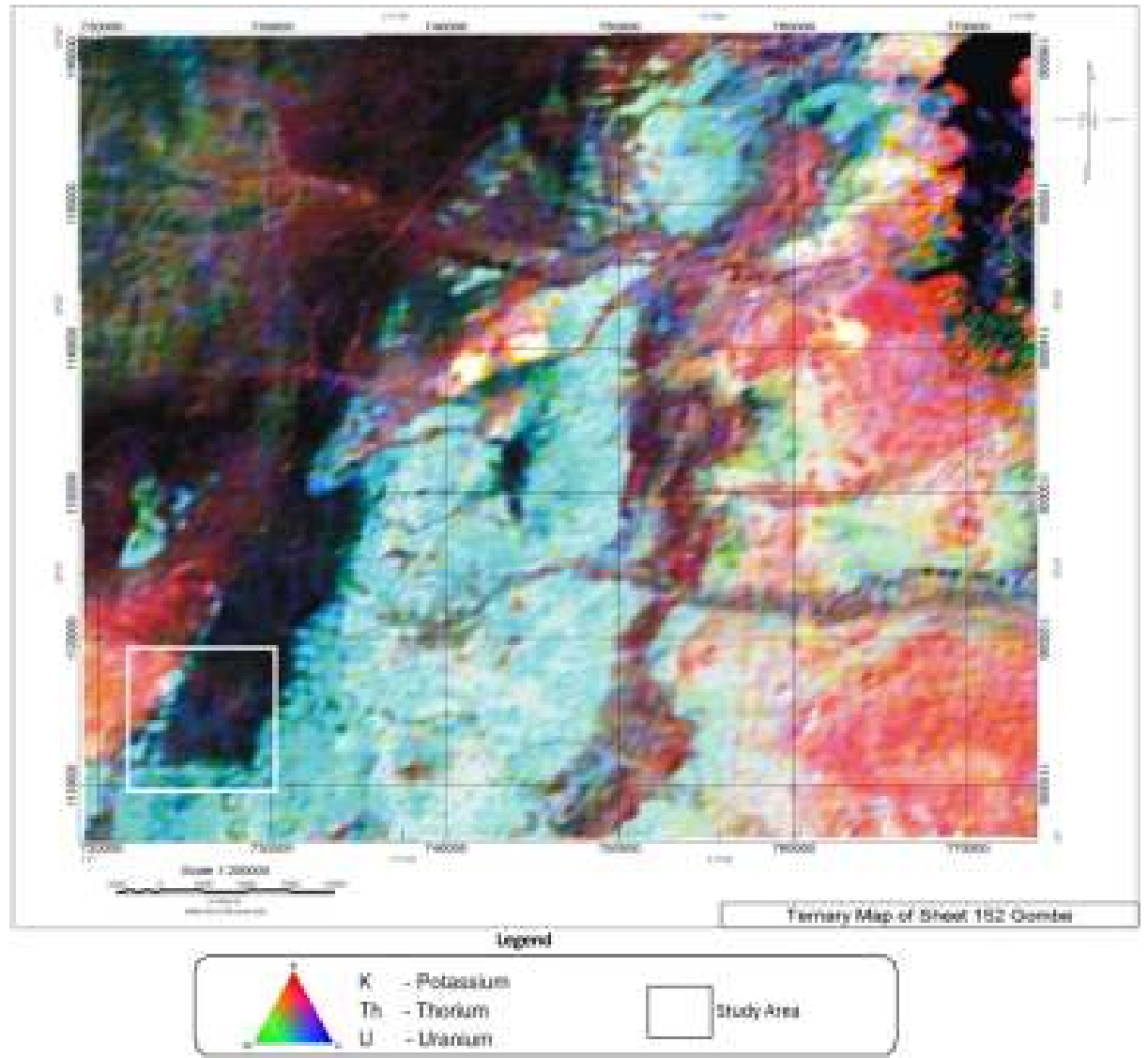

Fig- 1: Ternary lmage Map of Gombe Sheet 152 S.W. (Source: Nigerian Geological Survey Agency, 2009)

\section{LOCATION AND GEOLOGY OF THE STUDY AREA}

The proposed area of study is located between latitudes $10^{\circ} 02^{\mathrm{N}} \mathrm{N}$ to $10^{\circ} 07 \mathrm{~N}$ and longitudes $11^{\circ} 02^{\prime} \mathrm{E}$ to $11^{\circ} 06^{\prime} \mathrm{E}$ on the topographic map sheet 152 referred to as Gombe Sheet 152 S.W. Some parts of the Kerri-Kerri Formation and Gombe Sandstone lies in the study area. Fig. 2 shows the topographic map of the study area.

The Kerri-Kerri Formation was laid down in a Continental environment ranging from Lacustrine to Deltaic (Carter. et al 1963). It was derived from the weathering of the basement rocks as well as of Cretaceous Sedimentary Formations. It outcrops in the western part of the study area and lies unconformably on the Gombe Sandstone.
In the western part of the plateau, which coincides with the western edge of the area, the Kerri-Kerri Formation overlies the basement complex, but the contact is almost completely masked by abundant alluvial deposits. The maximum thickness of the formation is about 200m (Carter et al, 1963).

The Kerri-Kerri formation has not been subjected to folding and has the lowest fracture density of all the Formations present in the area. This is probably because it was laid down after the main tectonic phase has occurred, and on the poorly cemented nature of the lithological components of its upper part (Carter et al, 1963). 


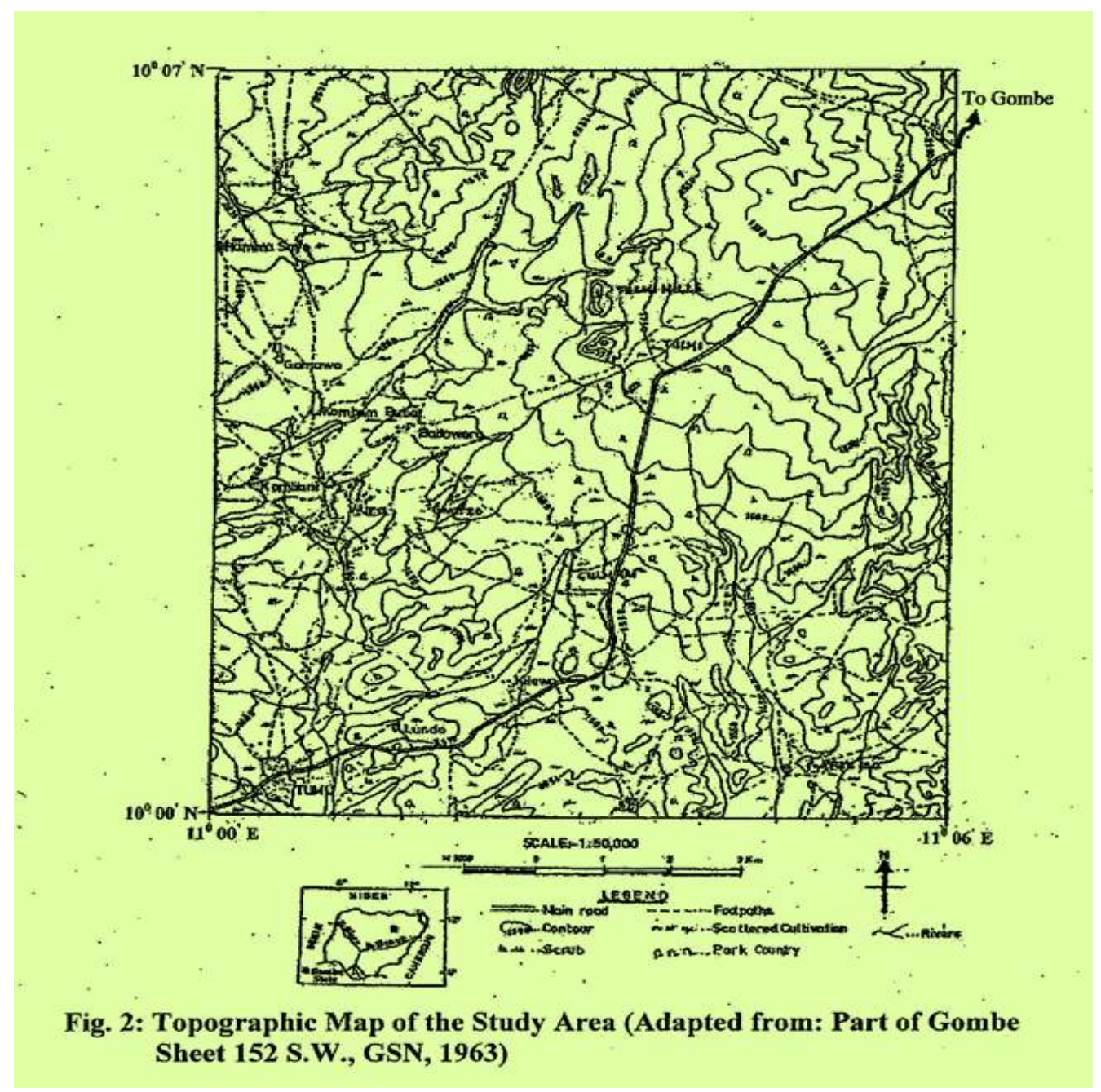

The stratigraphy consists from the youngest of Alluvium, Kerri-Kerri Formation, Gombe Sandstone, Pindiga Formation, Yolde Formation, Bima Formation and the Basement rocks as the oldest. Alluvium includes most soils and comprises of those deposits formed insitu by the chemical and physical decomposition of the bedrocks. Alluvium is generally poorly developed over the arenaceous member of the Cretaceous Formation. The extent of alluvium cover increases westward but it can be estimated that $10 \%$ of the Gombe Sandstone is covered by alluvium (Carter. et al 1963).

The Gombe Sandstone is a continental sequence of sandstone, shale, siltstones and ironstones, with maximum thickness of $300 \mathrm{~m}$ and its sequence can be divided into two parts: The Upper 223 $\mathrm{m}$ mainly consisting of sandstones and the lower which consist of shale containing ironstone layers up to $200 \mathrm{~m}$ thick (Carter et al, 1963).

The Gombe Sandstone outcrops in a narrow north - south belt on the western part of the study area where it unconformably lies on shale and limestone of the Pindiga Formation and is unconformably covered by the Kerri-Kerri Formation. The basement complex includes all the pre-Mesozoic rocks and is thus the oldest formation of the Nigerian Stratigraphic series. It is composed mainly of granites, gneisses and migmatites with subordinate basic rocks.

In the study area, remnants of highly metamorphosed sedimentary rocks are present here and there, mainly as xenoliths. In the northeastern part of the area it outcrops as biotite and coarse porphyritic granite and as anatetic migmatites around the GombeHill. The Gombe Sandstone is confined to the western part of the region where the outcrop follows a broad belt of country northwards from Kashere to Gombe and Fika.

Siltstones and flaggy sandstones form the greater part of the Gombe Sandstone. These rocks are soft and light grey in colour when fresh, but on exposure give rise to dark red, flaggy debris which characteristically mantles the Gombe Sandstone hills (Carter et.al, 1963).

The Gombe Sandstone is the top member of a folded and eroded sedimentary sequence and it is not possible to determine its original thickness; at least $1,000 \mathrm{ft}$, of strata are present in the area. Fig. 3 is the geologic map of the study area. 


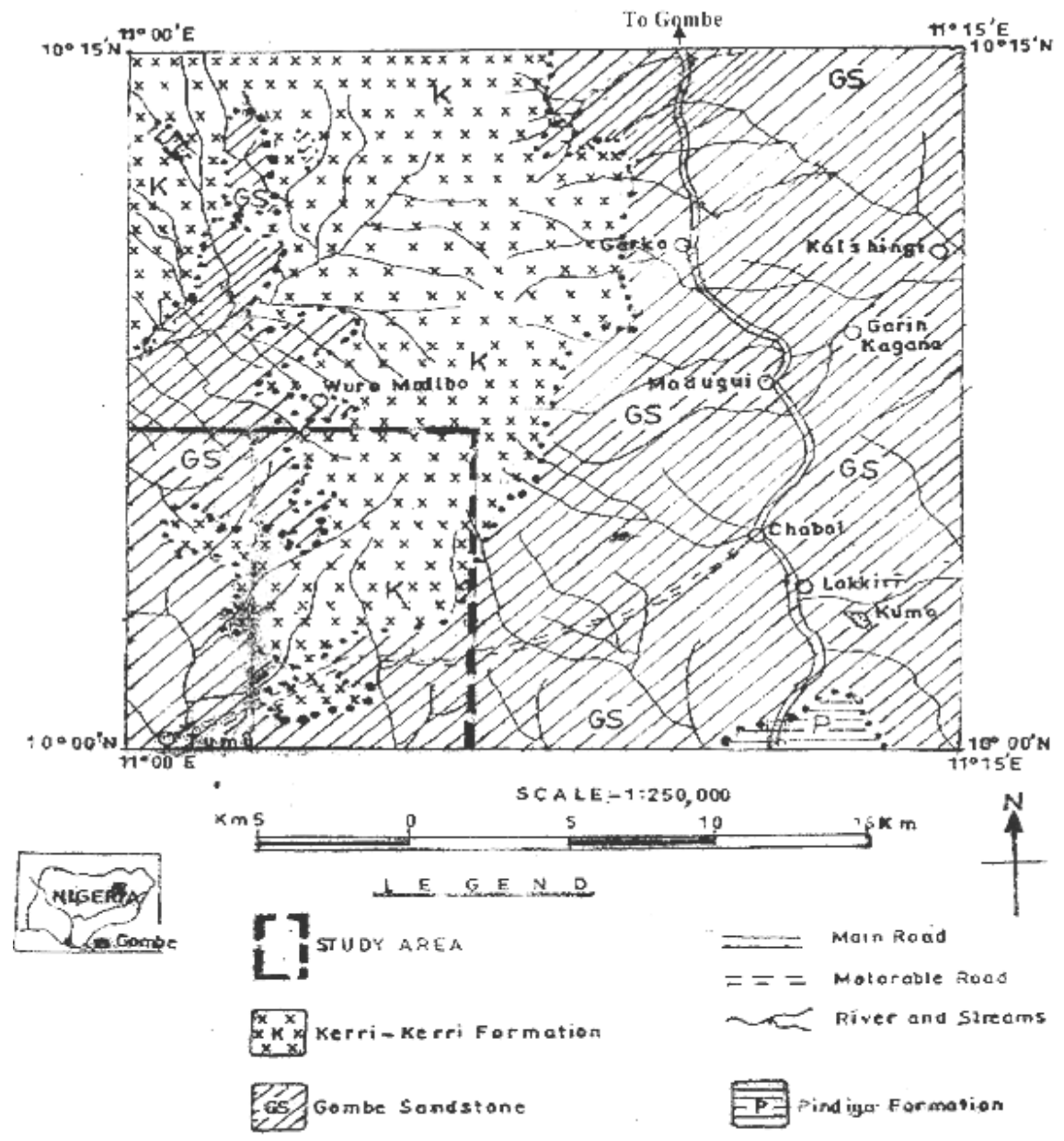

Fig. 3: Location of the Study Area within the Geologic Map of the Area (Source: Geological Survey of Nigeria, 1963)

\section{INSTRUMENTATION AND FIELD TECHNIQUES}

Exploranium ${ }^{\circledR}$ portable gamma ray scintillometer; model GR-101A, manufactured by Geometrics Inc California was used for the survey. The GR-101A scintillometer is an instrument that transforms incident gamma radiation into a visual read out of radioactive intensity as a function of the natural radioactive material present in the geologic formation (McDermott, 1977).

The scintillometric survey was carried out from $6^{\text {th }}$ to $16^{\text {th }}$ May, 2013 using the scintillometer (GR-101A) strapped at west height above the ground. The study area was traversed on foot and readings were taken at random points. The locations of the random points were also recorded from a GPS. Rock samples were also collected at different locations within the study area for identification. A total of three hundred and ninety four (394) total count readings were taken from the scintillometer and recorded during the period of the survey.

To estimate the cosmic ray contribution to the ground activity measured in the field, readings were taken in the middle of a Pond located at $10^{\circ} 12^{\prime} 09^{\prime \prime} \mathrm{N}$ and $11^{\circ} 03^{\prime} 17^{\prime \prime} \mathrm{E}$ (between Tulmi and Gulmari villages). The readings in the pond were taken first in the morning before the start of the survey and then in the evening for each day of the survey. The average background readings taken for the period of the survey in the Pond was $3.95 \mathrm{cps}$.

Two other sets of background readings were taken inside Dadin-Kowa

Dam which is located about $60 \mathrm{Km}$ east of the study area. This is to compare the background readings obtained in the dam with those obtained in the pond in the study area. The first set of background readings (i.e. morning and evening) were taken in the Dam on the first day of the survey while the second set of readings (i.e. morning and evening) were taken in the Dam on the last day. The average of the two sets of readings taken in the Dam is $3.125 \mathrm{cps}$. The background readings taken in the dam are lower because of the larger volume of water as compared to that of the Pond. The average cosmic ray contribution from the Dadin-Kowa Dam and the Pond is approximately $4 \mathrm{cps}$ which is used for background correction. A summary of the background readings taken in the pond and Dam is given in Table 1. 
Table 1: Background Readings taken in the Pond and Dadin - Kowa Dam

\begin{tabular}{|l|l|l|l|l|l|l|}
\hline \multirow{2}{*}{$\begin{array}{l}\text { Day/Date } \\
\text { Survey }\end{array}$} & \multicolumn{5}{|l|}{ Background Readings (cps) } \\
\cline { 2 - 7 } & \multicolumn{5}{|l|}{ Dadin Kowa Dam } \\
\hline & Pond in the Study Area & \multicolumn{2}{l|}{} \\
\cline { 2 - 7 } & Morning & Evening & Average & Morning & Evening & Average \\
\hline Mon. 6/5/2013 & 4.0 & 4.0 & .4 .00 & 3.0 & 3.00 & 3.000 \\
\hline Tue. 7/5/2013 & 4.0 & 5.0 & 4.50 & & & \\
\hline Wed. 8/5/2013 & 5.0 & 3.0 & 4.00 & & & \\
\hline Thur. 9/5/2013 & 4.0 & 3.0 & 3.50 & & & \\
\hline Fri. 10/5/2013 & 3.0 & 4.0 & 3.50 & & & \\
\hline Sat. 11/5/2013 & 4.0 & 4.0 & 4.00 & & & \\
\hline Mon. 13/5/2013 & 4.0 & 5.0 & 4.50 & & & \\
\hline Tue. 14/5/2013 & 5.0 & 3.0 & 4.00 & & & \\
\hline Wed. 15/5/2013 & 5.0 & 3.0 & 4.00 & & & \\
\hline Thur. 16-5-2013 & 3.0 & 4.0 & 3.50 & 3.0 & 3.50 & 3.250 \\
\hline Average & 4.1 & $\mathbf{3 . 8}$ & $\mathbf{3 . 9 5}$ & $\mathbf{3 . 0}$ & $\mathbf{3 . 2 5}$ & $\mathbf{3 . 1 2 5}$ \\
\hline
\end{tabular}

\section{DATA REDUCTION}

The data collected were corrected for background and contoured using the program SUFER 9 . The uncertainties attached to the count rates are the 90 $\%$ confidence limits of the mean activities. Contour map of the count rates produced is shown in Fig. 4. The count rates were generally higher in the south - western part of the study area as shown in Fig.4.
A prominent peak centered at $\left(10^{\circ} 00^{\prime} 42^{\prime \prime}, 11^{0}\right.$ 0127 ) is observed north - east of Tumu on the contour map. Observation in the field also reveals that areas identified with high total count readings coincide with areas with occurrence of granitic feldspars in the KerriKerri Formation while most of the areas with low count rates around Gulmari and Tulmi are areas with occurrence of alluvium in Gombe sandstone. 


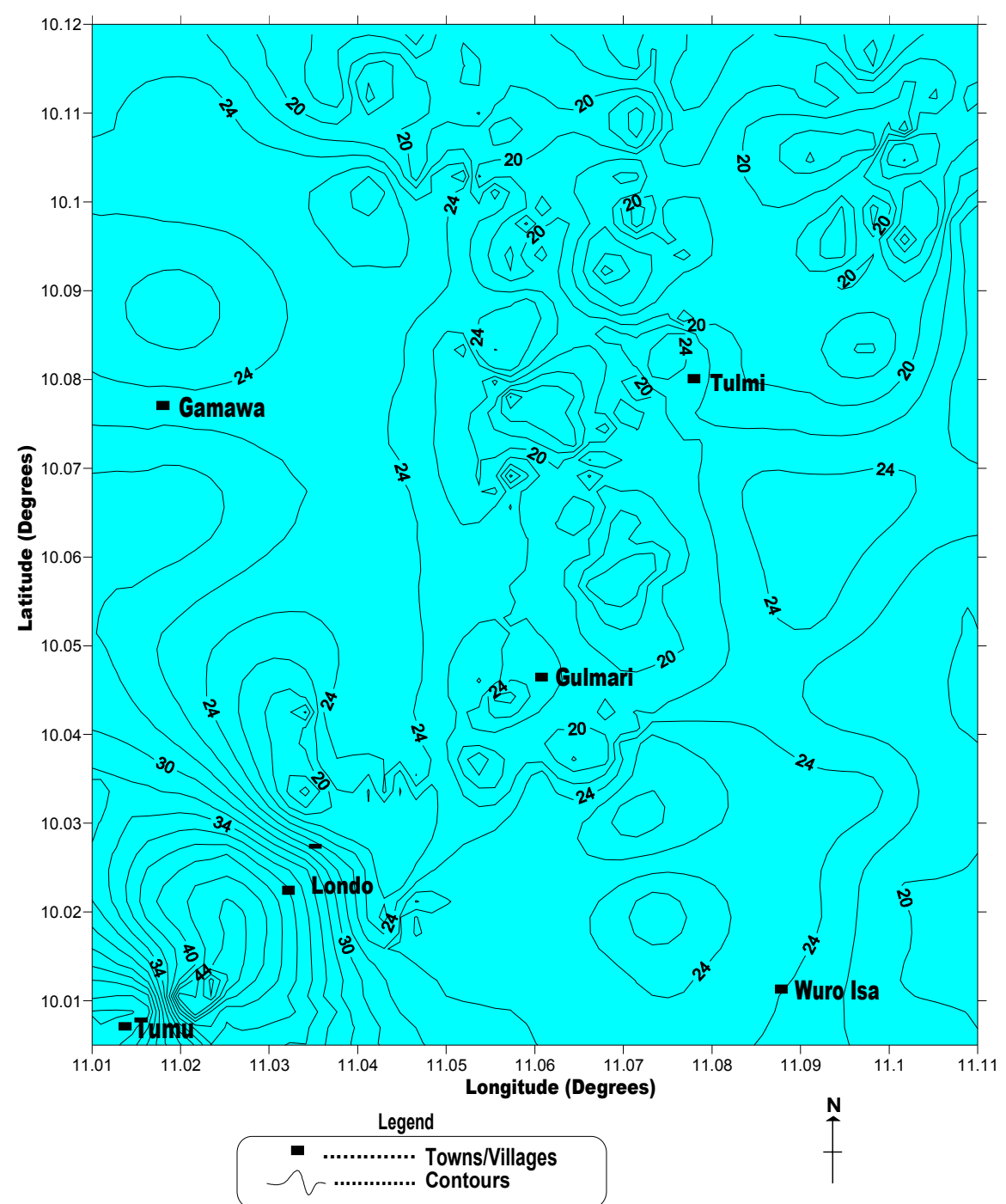

Fig. 4: Contour Map of Count Rates of Gamma Ray Energy of the Study Area (Contour Interval is $\mathbf{2} \mathrm{cps}$ ).

\section{DATA ANALYSIS}

Geologic formations are not necessarily uniform in radioactivity. As suggested by Ahmed (2006). An attempt has to be made in order to unify the errors that may arise in the calculations of the average values of field activities and of standard deviations. Areas of radioactive anomalies can be delineated from the total count contour map.

According to Uwah (1984), a better method of determining the average activity value for a geologic unit is to plot a frequency distribution of the number of data points with a given activity versus the activity. Fig.5 is the frequency distribution curve from the total count rates reduced data. 


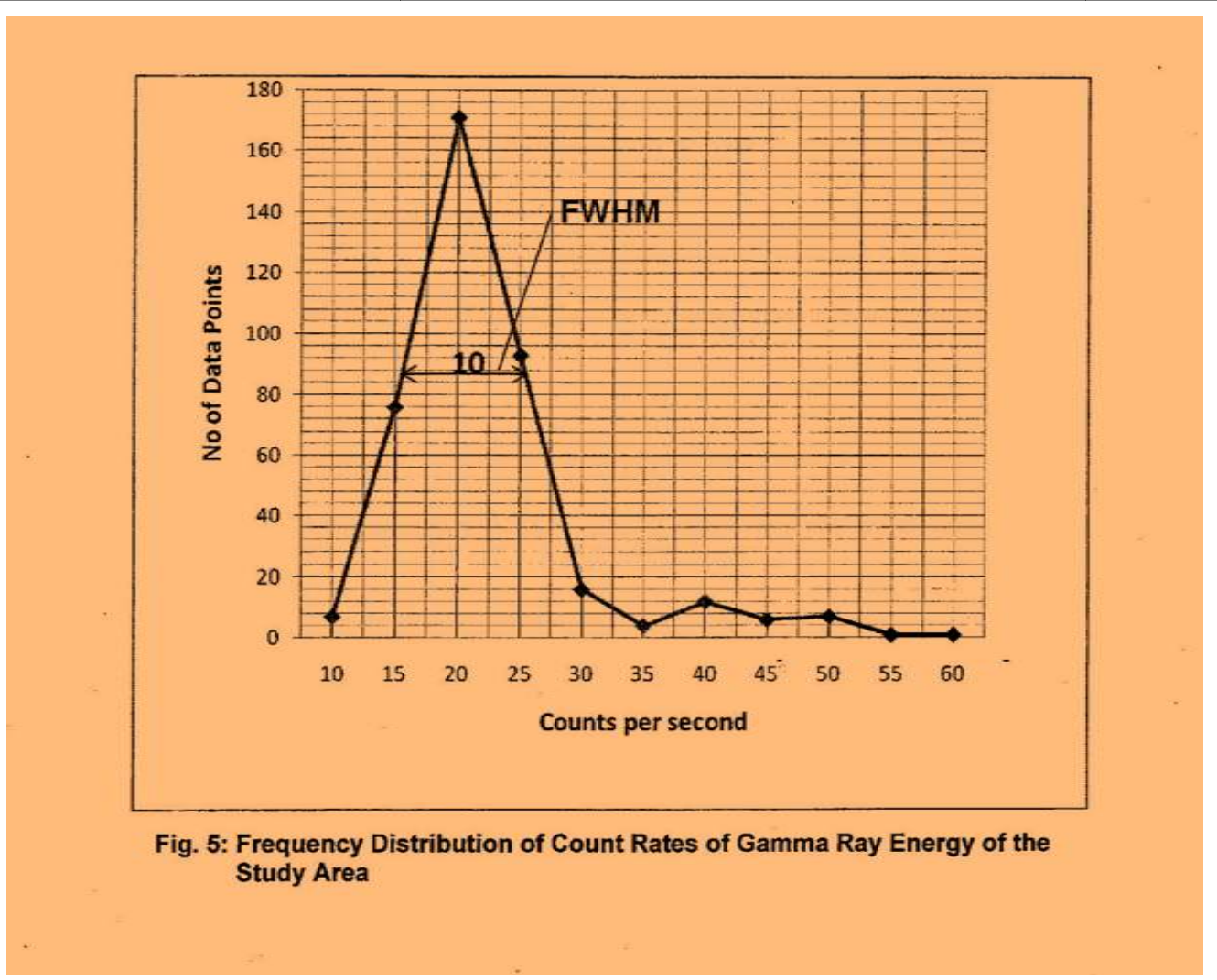

The mean activity in Fig. 5 is the mode of the frequency distribution.

The normal or the expected activity value for the study area was obtained from the frequency curve (Fig. 5) as follows:

The mode $=20 \mathrm{cps}$.

The full width at half maximum

$$
(\mathrm{FWHM})=10
$$

The standard deviation (SD) is then given by Duval (1979) as:

$$
\mathrm{SD}=\mathrm{FWHM} \times 0.75
$$

Therefore $S D=10 \times 0.75 \approx 8 \mathrm{cps}$

The normal or the expected mean activity value LB is then given by:

$$
\begin{aligned}
\text { LB } & =\text { Mode } \pm \text { SD } \\
& =(20 \pm 8) \mathrm{cps}
\end{aligned}
$$

The threshold value (the highest activity) is therefore 28 cps.

According to Uwah (1984), all other values higher than $28 \mathrm{cps}$ are considered anomalous. In Fig. 6, the approximate areas with sources of radiation which produce this anomaly (> $28 \mathrm{cps}$ ) are: north - east of Tumu, south- east of Gulmari and north - east of Gamawa. Therefore, only the anomaly in these areas as indicated with red contour lines (Fig. 6) may be significant in terms of radioelement mineralization.

According to Levinson (1974), for an activity to be of significance in terms of mineralization, it must be about twice the mean activity of the area. In the study area, activities of more than twice the mode (i.e. $40 \mathrm{cps}$ ) was observed at the south - western part of the study area, located north - east of Tumu as shown in Fig. 7 with red contour lines. 


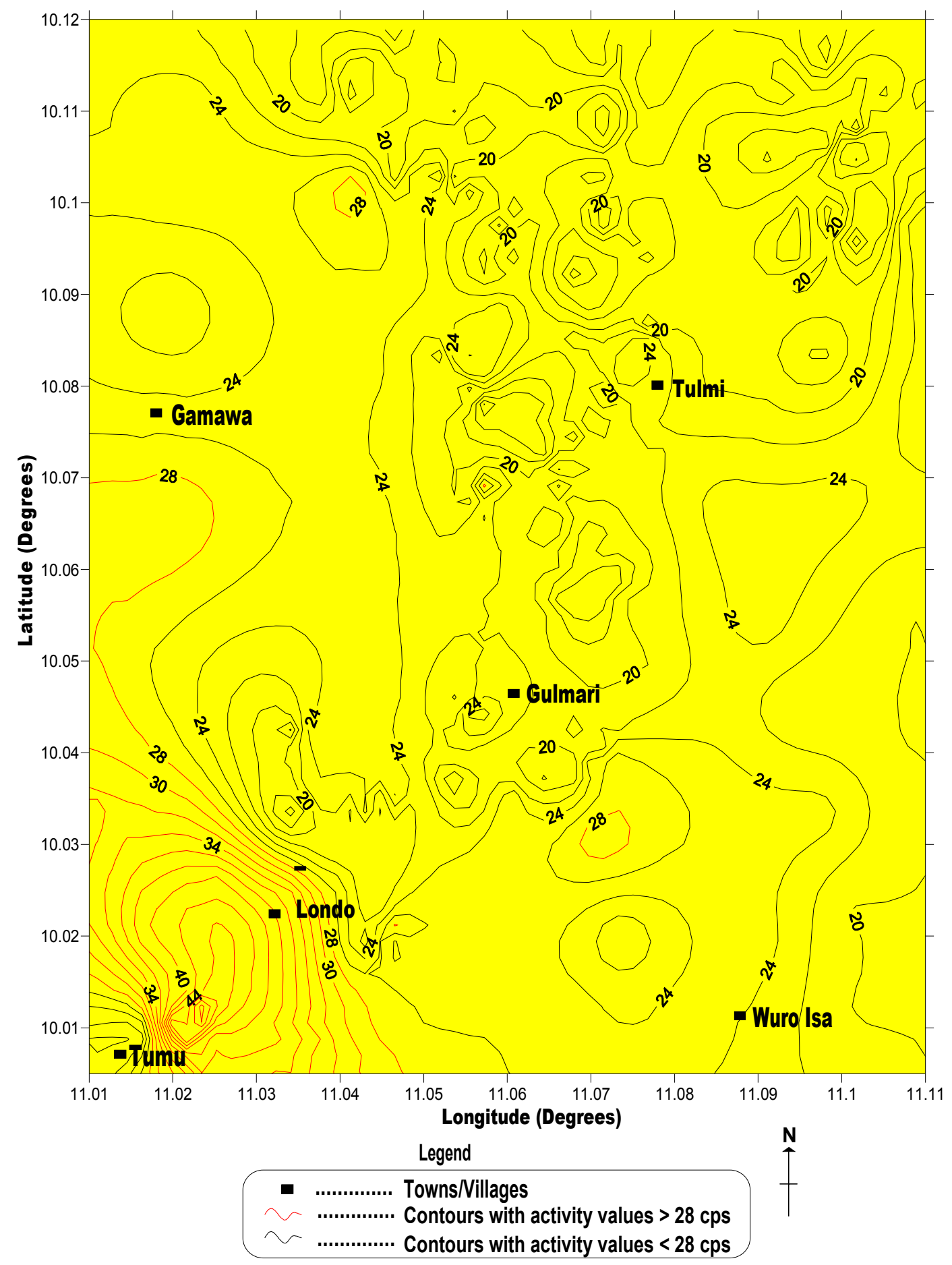

Fig. 6: Contour Map of Count Rates of Gamma Ray Energy ( $>28 \mathrm{cps}$ ) of the Study Area (Contour Interval is $2 \mathrm{cps}$ ). 


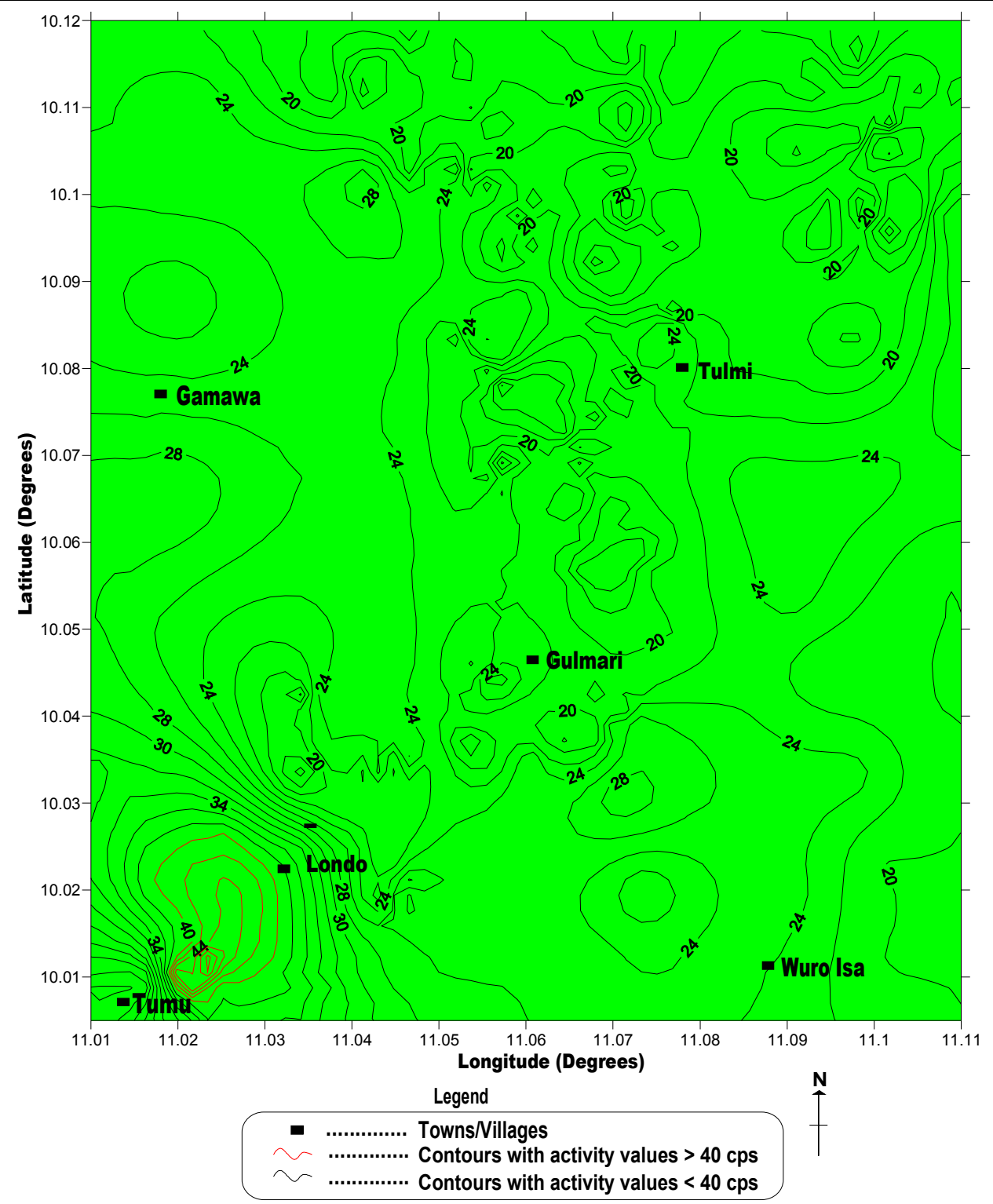

Fig. 7: Contour Map of Count Rates of Gamma Ray Energy ( $>40 \mathrm{cps}$ ) of the Study Area (Contour Interval is 2 cps).

\section{CONCLUSION}

An area of more prominent radiometric anomaly has been identified in the south - western part of the Kerr Kerri Formation. The area is to the north east of Tumu village as shown on the contour map of Fig. 7. The identified area should therefore be considered for further detailed ground spectrometric survey so as to determine the radiometric mineralization potentials of the area and also confirm if the radiation is coming from the soil or rocks of the area.

\section{REFERENCES}

Adepelumi, et.al., 2011. Reservoir characterization and evaluation of depositional trend of the Gombe sandstone, southern Chad basin Nigeria. Journal of Petroleum and Gas Engineering 2, (6): 118-131.
Ahmed A. L., 2006. Detailed Radiometric Surveys of the Albite Riebeckite Granites of Dutsen-Wai Ring Complex. Unpublished Ph.D. Thesis, Ahmadu Bello University, Zaria.

Arabi, et.al., 2009. Hydro Geo-Electrical Investigation in Gombe Town and Environs, Northeastern Nigeria. J. Appl. Sci. Environ. Manage. September, 2009 13, (3): $65-68$.

Carter, J. D., Barber, W., Tait, E. A and Jones, G. P., 1963. The Geology of Parts of Adamawa, Bauchi and Bornu Provinces in North-Eastern Nigeria. Geological Survey of Nigeria, Bulletin No. 50.

Dewu, B. B. M., 1989. "Distribution of Uranium in Granite and Mobility of Uranium during Low Temperature Alteration Processes". Unpublished Ph. D Thesis, University of Exeter, U.K. pg. 63-98. 
Doura M. A. K., 2011. Hydrogeophysical Investigation of Groundwater Potentials in Gombe Metropolis, Sheet 152 Gombe, North Eastern Nigeria. Unpublished B.Sc. Thesis, Gombe State University.

Levinson, A. A., 1974. Introduction to Exploration Geochemistry. Applied Publishing LTD: Maywood Illinois. pp 614.

McDermott, A., 1977. "Field Experiments with Exploration Model GR-101A". Geometrics Exploranium Model GR-101A Users Manual. pg 10.
Osazuwa, et.al., 1981. Analysis of the Structure of Part of the Upper Benue Rift Valley on the Basis of New Geophysical Data. Earth evolution sciences 2/1981.

Oshin, I. O., 1986. Uranium Favourability Study in Nigeria. Journal of African Earth Sciences, 2, 175-175. 